Discussion Paper No. 09-057

\title{
The Economics of Adaptation to Climate Change - The Case of Germany
}

Astrid Dannenberg, Tim Mennel, Daniel Osberghaus, and Bodo Sturm

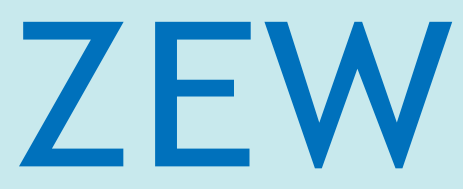

Zentrum für Europäische Wirtschaftsforschung $\mathrm{GmbH}$

Centre for European Economic Research 
Discussion Paper No. 09-057

\title{
The Economics of Adaptation to Climate Change - The Case of Germany
}

\author{
Astrid Dannenberg, Tim Mennel, \\ Daniel Osberghaus, and Bodo Sturm
}

Download this ZEW Discussion Paper from our ftp server:

ftp://ftp.zew.de/pub/zew-docs/dp/dp09057.pdf

Die Discussion Papers dienen einer möglichst schnellen Verbreitung von neueren Forschungsarbeiten des ZEW. Die Beiträge liegen in alleiniger Verantwortung der Autoren und stellen nicht notwendigerweise die Meinung des ZEW dar.

Discussion Papers are intended to make results of ZEW research promptly available to other economists in order to encourage discussion and suggestions for revisions. The authors are solely responsible for the contents which do not necessarily represent the opinion of the ZEW. 


\section{Non-technical summary}

Adaptation to climate change is becoming increasingly important in the political and scientific debate. The reason for this is that climate change impacts are visible already today and will intensify in the next decades. Furthermore, the prospects for an effective international agreement on climate policy with binding emission reduction targets are uncertain. The economic analysis of adaptation, however, is still in its infancy with a few economic studies covering specific aspects of adaptation. Therefore, this paper aims at developing a broad economic framework for adaptation which can provide a foundation and a starting point for future economic research. The economic analysis allows us to distinguish between autonomous adaptation by private agents on the one hand and collective adaptation measures by government entities on the other. Our theoretical economic approach follows the basic economic paradigm of efficient competitive markets where government intervention is justified by market failure only. The most important case of market failure in adaptation is the provision of public goods, such as dykes or weather information systems. Moreover, we discuss further political objectives, namely equity and security of supply, in the context of adaptation to climate change. The approach developed in the theory part is then applied to the case of Germany. Due to its size and geography as well as its relatively diversified sectoral structure Germany is a good example to analyze and develop adaptation measures in climate sensitive sectors in industrialized countries, particularly in Europe. The case study on Germany which is based on the available literature covers sectors that are particularly vulnerable to climate change, namely agriculture, energy, water and coastal protection, and human health. While from an economic perspective adaptation in agriculture and energy should predominantly be autonomous, the government has a role in the sectors water, coastal protection and health. The results indicate that in Germany beside the negative impacts of climate change positive impacts are to be expected in some sectors, such as agriculture. Therefore a differentiated adaptation strategy by consumers, producers, and policy makers requires more research into the climate impacts on different sectors of life and the economy. 


\section{Das Wichtigste in Kürze}

Das Thema Anpassung an den Klimawandel gewinnt eine immer größere Bedeutung in der politischen und wissenschaftlichen Debatte. Eine Ursache hierfür liegt in dem bereits heute spürbaren Klimawandel, der sich in den nächsten Jahrzehnten weiter beschleunigen wird. Zugleich müssen die Erfolgsaussichten eines effektiven globalen Klimaschutzabkommens als unsicher eingeschätzt werden. Die ökonomische Analyse der durch den Klimawandel bedingten Verhaltensänderungen steht jedoch erst am Anfang - die wenigen verfügbaren Studien beschränken sich oftmals auf spezifische Anpassungsaspekte. Vor diesem Hintergrund verfolgt die vorliegende Arbeit das Ziel, einen allgemeinen ökonomischen Ansatz für eine wirtschaftspolitische Analyse der Anpassung an den Klimawandel zu entwickeln. Dieser ökonomische Ansatz erlaubt eine Unterscheidung zwischen autonomer Anpassung privater Akteure einerseits und kollektiver Anpassung staatlicher Institutionen andererseits. Die Arbeit folgt dem ökonomischen Grundparadigma effizienter Wettbewerbsmärkte, in dem Eingriffe des Staates zunächst nur bei Marktversagen zu rechtfertigen sind. Bei Anpassungsmaßnahmen ist die wichtigste Form von Marktversagen die Bereitstellung öffentlicher Güter, wie z.B. der Deichbau oder meteorologische Informationssysteme. Außerdem werden weitere Motive politischen Handelns, Verteilungsgerechtigkeit und Versorgungssicherheit, im Zusammenhang mit Anpassungsmaßnahmen diskutiert. Aufbauend auf der allgemeinen ökonomischen Analyse der Anpassungsmaßnahmen an den Klimawandel wendet die Arbeit die gewonnenen Erkenntnisse auf den Fall Deutschlands an. Aufgrund seiner Größe, seiner geografischen Lage und seiner sektoralen Struktur stellt Deutschland ein geeignetes Fallbeispiel dar, um Effekte des Klimawandels und die Entwicklung geeigneter Anpassungsstrategien in Industriestaaten, vor allem in der Europäischen Union, zu untersuchen. Die Ausführungen basieren auf der verfügbaren Literatur und umfassen die folgenden, vom Klimawandel besonders betroffenen Sektoren: Landwirtschaft, Energie, Wasser und Küstenschutz sowie Gesundheit. Während aus ökonomischer Sicht bei Landwirtschaft und Energie Anpassung vor allem von privaten Akteuren geleistet werden sollte, gibt es in den Sektoren Wasser, Küstenschutz und Gesundheit eine Reihe von Staatsaufgaben. Die Ergebnisse zeigen zudem, dass in Deutschland neben den negativen Wohlfahrtseffekten des Klimawandels in einzelnen Bereichen, wie z.B. in der Landwirtschaft, auch positive Auswirkungen zu erwarten sind. Eine differenzierte Anpassungsstrategie von Konsumenten, Unternehmen und staatlichen Entscheidungsträgern erfordert deshalb eine vertiefte Erforschung der Klimaveränderungen und auswirkungen in einzelnen Sektoren und Lebensbereichen. 


\title{
The Economics of Adaptation to Climate Change - The Case of Germany
}

\author{
Astrid Dannenberg ${ }^{\mathrm{a}}$, Tim Mennel ${ }^{\mathrm{a}}$, Daniel Osberghaus, ${ }^{\mathrm{a},{ }^{*}}$, and Bodo Sturm, ${ }^{\mathrm{a}, \mathrm{b}}$ \\ ${ }^{\mathrm{a} C e n t r e ~ f o r ~ E u r o p e a n ~ E c o n o m i c ~ R e s e a r c h ~(Z E W), ~ M a n n h e i m ~}$ \\ ${ }^{\mathrm{b}}$ Department of Business Administration, Leipzig University of Applied Sciences \\ * Corresponding author \\ E-mail: \\ dannenberg@zew.de,mennel@zew.de, \\ osberghaus@zew.de,bodo.sturm@wiwi.htwk-leipzig.de
}

September 2009

\begin{abstract}
Given the ubiquitous scarcity of resources an economic approach is necessary in order to determine an optimal strategy of adaptation to climate change. In this paper we develop an economic framework for the study of adaptation which allows us to distinguish between decentralized adaptation by private agents on the one hand and centralized adaptation measures by public authorities on the other. The approach is based on the paradigm of market failure and is complemented by two further grounds of government action, equity concerns and security of supply. We identify open research questions in the nascent field of adaptation to climate change requiring further empirical investigation. The economic framework is applied to adaptation in Germany by analyzing impacts and adaptation options for climate-sensitive fields such as agriculture, energy, water, and public health.
\end{abstract}

JEL classification:

Keywords:
Q54, Q58

climate change, adaptation, market failure, insurance 


\section{Introduction}

Climate change is a challenge to societies and economies around the globe. Basically, policy makers have two options: they can try to slow down and possibly halt climate change (mitigation), or they can accept the change and let their economies at least partially adapt to it (adaptation). Both strategies involve costs: On the one hand, carbon abatement requires the usage of new and comparably expensive technologies, e.g. renewable energy sources. On the other hand, adjustments to the effects of a changing climate require private and public resources, e.g. the use of air conditioning and the construction of flood protection systems. Both strategies are not mutually exclusive: An optimal global policy should counterbalance mitigation and adaptation, minimizing the sum of costs caused by mitigation, adaptation, and residual damages. Nordhaus (1991) derives two conditions for such a cost minimum: First, the marginal costs of emissions reduction should be equal to the marginal benefits of emission reduction, i.e. the avoided marginal residual costs of climate change. Second, adaptation should be realized up to the point where the marginal benefits of adaptation are equal to the marginal costs of adaptation. There is a trade-off between both policy options at the global level: More emissions reduction makes less adaptation necessary and vice versa. ${ }^{1}$ of course this stylized global perspective has its theoretical pitfalls and practical limits. Accounting for costs of both mitigation and adaptation of climate change is an enormous scientific endeavor, involving branches of agricultural scientist, geologist, meteorologists, and economists. Uncertainties about future developments require a choice of risk evaluation. ${ }^{2}$ Aggregating costs is not innocuous - it means that distributional issues are neglected. Also, the viewpoint may not be appropriate for real world politics: As there is no benevolent king enforcing a global cost-benefit analysis, any mitigation effort will depend on the outcome of international negotiations between sovereign nations which are likely to pursue their particular interests in the implementation of climate policy. Finally, in the real world, as emphasized by Tol (2005), adaptation and mitigation are done by different people operating at different spatial and temporal scales. This hampers the theoretically possible trade-off between adaptation and mitigation. Therefore, at the national level, adaptation policy

\footnotetext{
${ }^{1}$ Already Schelling (1992) is talking about a second trade-off between mitigation and adaptation. Higher mitigation efforts may lead to a lower growth rate and therefore to a lower adaptive capacity of an economy. Tol (2007) is referring to this effect as the "double trade-off between adaptation and mitigation". This effect is, however, not discussed here.

${ }^{2}$ Recent studies suggest that uncertainty about low-probability-high-impact events may limit the applicability of a costbenefit analysis (Tol 2003, Weitzman 2007, 2009).
} 
can be treated as a field of action independent from mitigation policy that is determined on an international level.

Despite of its likely relevance adaptation has so far been considerably less prominent in the public, scientific and economic debate about climate change than mitigation. In Germany, for example, as early as 1992 the parliamentary committee of enquiry "Protection of the earth atmosphere" was established (Deutscher Bundestag 1992). The focus of this commission was almost entirely on mitigation and impacts. The National Adaptation Strategy (BMU 2008), however, was published only in 2008. This emphasis on mitigation is representative for European countries, as Tol (2005, p. 572) phrases bluntly: “For a long time, it was politically incorrect to speak about adaptation to climate change, because it presumably implies accepting defeat in the battle against evil emissions [...] This has changed [...]".

There are at least two main reasons for the shift in perception. First, climate change is already observable and - given the inertia of the climate system - will inevitably intensify (IPCC 2007a and EEA 2008). In other words, even if the world will not warm more than $2^{\circ} \mathrm{C}$ above pre-industrial temperatures, a target proposed by the EU (CEU 2004), adaptation is necessary. Second, due to the well-known free rider incentives in international negotiations on climate policy, the prospect for a binding agreement restricting world's emissions sufficiently to halt climate change are at least uncertain (Helm 2008). Consequently, adaptation is increasingly gaining weight on the political and scientific agenda.

This paper aims at developing a normative economic framework for adaptation - a framework which allows to distinguish between decentralized adaptation by private agents on the one hand and centralized adaptation measures by governmental entities on the other. The ubiquitous scarcity of resources makes an economic approach necessary in order to determine an optimal degree of adaptation. The perspective we take is the one of a sovereign state - not an international arena, where regulation is difficult to enforce. The efficiency-oriented approach is based on the paradigm of market failure and is complemented by two further grounds of government intervention, equity concerns and security of supply. Moreover, we identify open research questions in the nascent field of adaptation to climate change requiring careful empirical investigation.

The framework developed in the theory part is applied to the case of Germany. Due to its size and geography, private and public decision makers in Germany have to cope with various effects of climate change, positive as well as negative depending on the region and sector. Both private and public actors have to develop adequate strategies how to gain from potential benefits and how to 
limit adverse effects. Given its relatively diversified sectoral structure, the case of Germany can serve as an example for the development and implementation of adaptation measures in climate sensitive sectors in industrialized countries, in particular in Europe.

Climate change has different faces in Germany. Starting from the North, the two coastlines at North Sea and Baltic Sea are endangered by a rising sea level (Sterr 2008) and possibly by an increased risk of storm surges (Storch et al. 2007). In winter, regional climate projection models also calculate a considerable rise of mean precipitation by up to $30 \%$ of current precipitation (UBA 2008). In contrast, Eastern Germany may experience severe water shortages in summer, since summer precipitation is expected to decrease and parts of Eastern Germany already today have a negative water balance (UBA 2005). Along with a general trend to higher temperatures throughout Germany, heatwaves are expected to occur more often and the number of cold days will decrease. Adverse health affects due to temperature stress or an increased risk of vector-borne and food-borne diseases are likely to ensue. The risk of heat waves holds especially for urban areas in the South-West, where temperatures are relatively high today already and are predicted to rise by $2^{\circ} \mathrm{C}-4^{\circ} \mathrm{C}$, depending the climate projection model and IPCC emission scenario. Further in the South, Germany borders on the Alps and is affected from a retreat of glaciers and considerable decrease of snow coverage and snow reliability, with adverse effects on ecosystems as well as winter sports tourism. Another very important impact of climate change is the increasing probability of extreme weather events. Such extreme events encompass drought periods, heavy rainfalls with floods, hail, and storms. These extreme weather events are expected to occur more often in all parts of Germany given the current, inevitable climate change. Exact predictions of extreme weather events and their regional frequency are difficult to make with occurrence strongly depending on local and temporal conditions (UBA 2008, Schönwiese et al. 2005).

This paper proceeds as follows: In section 2 we develop the theoretical framework for an economic analysis of adaptation. We use the economic paradigm of market failure, and discuss equity aspects and security of supply as two additional motives for policy making. Applying the economic arguments to practical issues, section 3 shows which climate change impacts are to be expected for Germany, highlights the main vulnerabilities and proposes appropriate adaptation strategies. We focus on agriculture, energy, water and coastal protection, and public health. Section 4 concludes and gives an outlook on future research. 


\section{Theoretical framework for adaptation}

In this section we focus on the theoretical framework for adaptation by private and public actors. As for a definition, we follow the IPCC (2007) that defines adaptation as the "[a]djustment in natural or human systems in response to actual or expected climatic stimuli or their effects, which moderates harm or exploits beneficial opportunities.” Taking a nationally-oriented perspective we analyze which institutions are necessary to realize the optimal level of adaptation. Thereby the borderline between adaptation by private agents and adaptation by the government is set by the concept of market failures. Furthermore, we discuss how uncertainty may affect the design of optimal adaptation policy and how adaptation impacts insurance markets. Finally, we discuss equity and security of supply issues that arise in the context of adaptation.

\subsection{Efficient Private and Public Adaptation}

Normative economic theory rationalizes public policy intervention into private markets by market failure - in theses cases the government can enhance economic efficiency by specific regulation. Another rationale for public policy is distributive justice: While there is no consensus about the value of equity in economics (nor society), economists study efficient redistribution for a given equity target and spots equity-efficiency trade-offs (Atkinson and Stiglitz 1980) This rationale also applies to the challenge of adaptation to climate change as described in this section. In particular, governmental adaptation measures can be economically justified if they take the form of public goods or social insurance. Furthermore, climate change as well as adaptation policy can affect redistribution, thus leading to the need for adjustment of social policy.

At first we consider adaptation measures under certainty. The provision of public goods is a typical case of a market failure (Bator 1958): as their consumption value is not limited to a single consumer, free-riding leads to under-provision by private investors, in particular in the case of perfect public goods that are non-excludable and non-rival. In our framework, a dyke sheltering an agglomeration from flooding is the central example: No individual in the agglomeration can be excluded from the increase in security provided by the dyke. This makes a tax-financed public investment in the dyke socially efficient. If, in contrast, all benefits from reducing the damage of climate change (or from increasing benefits from it) accrue to an individual only, e.g. by air- 
conditioning of his home, private provision is efficient ${ }^{3}$ and public intervention is not warranted. The argument holds not only for consumption of private households, but also for intermediary goods in production. Following the literature, we label this form of adaptation autonomous, while adaptation undertaken by groups or public institutions will be called collective. ${ }^{4}$

The efficiency of autonomous adaptation hinges on the assumptions of full information on climate change and competitive markets. Take the following example: Under changing precipitation patterns an electricity company will efficiently plan and invest into a hydro power plant, but basic hydrological research into the development of water flows should be conducted at public research institutes. The reason is that information has public good properties. Apart from producing and distributing information that help economic agents to better understand the nature and impacts of expected climate change, the public goods provided as part of adaptation are infrastructure goods: either specific infrastructure of protection, such as dykes, or existing infrastructure, such as roads, railway systems or energy networks ${ }^{5}$, that have to be adapted to endure climatic changes.

An important question for economic research concerns the optimal degree of provision of public goods under climate change. Theory provides us with Samuelson's rule (1954): the sum of all marginal benefits from public adaptation should equal the marginal costs of public investment. Two points are important to note: First, the provision of a public good can become too costly - in some cases, e.g., it may be socially preferable to give up an agglomeration if the construction of flood protection exceeds reasonable cost limits. Second, in spite of the general notion of non-rival consumption of public goods ("everybody can enjoy a landscape”), in the real world public goods often have a local or regional character: A dyke usually protects a certain city, not a whole country the local, not the national population is the beneficiary. In so far the construction of a dyke can alternatively be characterized as an example of collective adaptation: a group engaging in collective action where the marginal costs of the measure exceed the benefits for each individual, but the sum of marginal benefits is greater than marginal costs. According to the theory of fiscal federalism (Oates 1999), it is efficient to assign the task of providing the local public good to the local authorities and tax-payers: The construction of a dyke providing shelter to one city only accrues to municipal authorities and local taxpayers. This view on local public goods can be altered by negative

\footnotetext{
${ }^{3}$ Formally, individuals will equate marginal costs of the measure to marginal benefits, leading to a socially optimal solution.

${ }^{4}$ Mendelsohn (2000) uses the terms private and joint adaptation.

${ }^{5}$ The latter are usually imperfect public goods, as they are excludable: e.g. consumers can be disconnected from an electricity grid.
} 
externalities. Economists refer to the term externality or external costs if an economic transaction negatively or positively affects a party outside the transaction (not accounting for relative price changes). The prime example is pollution from a production process that affects the public and therefore requires governmental regulation. In the case of local public goods, if their provision in one locality (i.e. collective adaptation of one group) has a negative impact on other localities (i.e. adaptation measures by other groups), uncoordinated actions by the localities (or groups) will be socially inefficient. ${ }^{6}$ In that case planning by a central government can ensure the socially efficient outcome. In reality conflicts of interest between political leaders of central and local authorities can well lead to inefficiencies. Moreover, adaptation measures sometimes may not be so easily disentangled - so any detailed study of a centrally planned adaptation measure has to take a possible crowding out of autonomous adaptation into account.

One important public good in the discussion of climate change is information. The efficiency of markets hinges on the assumption of full information among economic actors - asymmetries of information distort market outcomes. ${ }^{7}$ In the case of adaptation, this refers primarily to information about climate change - sellers and buyers of property, e.g., should have the same information about the regional exposure to climate change risk. Further examples of information asymmetries occur in the insurance market - they are discussed below.

A final important role of a central government is the establishment of an institutional framework of property rights. Without a functioning property rights system long-term investments which are crucial for several adaptation strategies will not take place, endangering both public and autonomous adaptation. An example would be the property rights to a water source that are the prerequisite for the construction of an agricultural irrigation system.

\subsection{Adaptation strategies under uncertainty and irreversibility}

So far we have neglected the aspect of uncertainty in climate change. Clearly, uncertainty matters for climate change: scientific uncertainty concerning the expected regional effects, impact uncer-

\footnotetext{
${ }^{6}$ For instance, building dykes by a local authority in order to prevent river floods up-stream may increase the risk of floods downstream. In a non-cooperative environment, an up-stream decision maker will not take into account the negative externality for the down-stream region generated by the dyke.

${ }^{7}$ In the case of incomplete information, the efficiency of markets is not guaranteed. This does not imply, though, that government intervention is always a possible or sensible solution. Often, elicitation of information is costly. In this case, the efficiency of a market transaction has to be traded-off against the cost of providing information.
} 
tainty concerning the economic impacts, and policy uncertainty (Heal and Kriström 2002). In this section we will describe the framework to analyze optimal strategies of adaptation under uncertainty. ${ }^{8}$ The next section will discuss another aspect of uncertainty - adaptation of insurance markets to changing climate conditions and a higher likelihood of extreme weather events.

Uncertainty and the option to wait for better information may have an effect on the optimal adaptation behavior, in particular if decisions are irreversible. This is the topic of real option theory (Dixit and Pindyk 1994), which studies optimal behavior under irreversibility, uncertainty and learning. Uncertainty about the exact nature of climate change impacts at the local and regional level makes it difficult to fine-tune adaptation measures. However, private actors and the government are likely to learn more about local impacts as time proceeds. Adaptation benefits (avoided climate damages) occur in the future - so they should be interpreted as expected benefits. In contrast costs for longterm adaptation projects, such as investment in climate-proof infrastructure (e.g. for transportation or energy networks) are certain and typically irreversible (i.e. after the investment costs are sunk). At the same time, the timing of the investment is for the investor to choose - it can be delayed if appropriate, e.g. instead of building a dyke now the policy maker can wait for better information regarding the likelihood of a flooding in his agglomeration. Real option theory studies the effect of flexibility on optimal action. In the case of adaptation measures - both by private or public actors given uncertainty with respect to the expected regional effects of climate change, the benefits of the investment in an adaptation project have to exceed the costs by a positive amount (so-called hurdle rate), in order to justify the investment. This amount is the "option value” not to invest but to wait and to delay the project. In other words, the classic rule according to which the present value has to cover at least the costs of investments does not hold under these circumstances. The optimal solution of this problem includes the comparison of investment costs and present values at all possible time slots, i.e. it has to be taken into account that the investment is possible at different time slots. Using the option to wait, an investor can possibly gain new information about future benefits (but also about better adaptation techniques which may reduce costs) and can adapt his behavior to changed conditions. Real option effects can work into the opposite direction, too: Cheap options for

\footnotetext{
${ }^{8}$ We refer to Arrovian uncertainty only - i.e. uncertain events where the probability distribution is known. There has been little to no study so far how to assess Knightian uncertainty in the context of climate change, i.e. uncertainty over events with unknown probability distribution.
} 
adaptation or mitigation may disappear or become more costly as climate change intensifies over time. An appropriate analysis of an adaptation strategy has to incorporate this aspect too. ${ }^{9}$

\subsection{Adaptation and insurance}

This section analyses the theoretical framework of insurance markets and their relevance for adaptation. Climate change tends to increase the frequency and severity of extreme weather events (IPCC 2007a). Worldwide damages from extreme weather events have clearly increased in the last decades. Schmidt et al. (2009) calculate that even if controlling for effects such as population changes, inflation, increased wealth or changes in settlement behavior, there is a significant positive correlation between natural disasters and global temperature.

The insurance sector can play an important role in addressing the uncertainty with respect to local effects of climate change. Principally, insurance markets are able to provide protection against climate-induced losses. The transfer of risk from risk-averse subjects to risk-neutral insurance companies leads to welfare improvements and an efficient level of precaution. Given an appropriate institutional framework - in particular a property rights system and functioning credit markets - insurance markets will find an efficient reaction to climate change. The effectiveness of insurance markets for climate adaptation may be hampered, though, by informational problems (adverse selection and moral hazard problems), requiring some form of government intervention.

Let us briefly recall the basic paradigms of insurance markets, as studied by the theory of expected utility (Schoemaker 1982, Gollier 2000). The theory of insurance generally assumes many riskaverse customers facing independent risks who pay premiums to a risk-neutral insurer in exchange for protection against possible future losses. Using the law of large numbers and knowledge about the distribution of risk an insurance company in principle takes a risk-neutral position - the total expected value of damages is equal to the total value of expected revenues. When customers have no real influence over risks insurance policies are relatively simple and parties frequently purchase complete coverage which is the socially optimal outcome. More often, however, customers can influence risks - think of settlement behavior that can influence the risk of a flood damages. This type of problem in insurance markets, which arises from the impossibility to control the behavior of the insured, is labeled moral hazard problem (Arrow 1963). Most often, the socially optimal out-

\footnotetext{
${ }^{9}$ See Fankhauser (2006) for a discussion of incentives for early investments in adaptation projects when climate change damages in the near future can be avoided.
} 
come - perfect insurance and sufficient precaution - cannot be achieved under these circumstances, but only a second best insurance contract with varying premia and partial coverage, trading off the insurance motive and the reduction of moral hazard. The second type of problem is commonly known as adverse selection (Rothschild and Stiglitz 1976): As an insurance company cannot distinguish between high-risk and low-risk customers - the risk is private information - it has to offer one insurance contract to all, pooling all risks. The implicit redistribution of such a scheme from low to high-risk type may lead to the breakdown of the insurance market when low-risk types find the premium too high and withdraw. Generally speaking we can say that distortions of insurance markets occur if insurance takers or insurance companies have incomplete information or misperceive risks, i.e. information is distributed asymmetrically. Sometimes insurance is not offered because risks are hard for insurance companies to estimate. In particular this is the case if the probability of a catastrophic event is very low so that the law of large numbers can no longer be applied. These difficulties are highly relevant for adaptation to climate change because the probability of extreme weather events is not only uncertain but also changes with global warming (MüllerFürstenberger and Schumacher 2008). Another problem arises if the risks faced by different insurance takers are non-independent which is likely to be the case with climate change damages. Insurance companies then cannot be confident of meeting their costs and they will therefore tend to charge higher premiums, presuming some degree of risk aversion on their part. In this case, the insurance takers expected utility will be maximized if they obtain less than full coverage of damages (Shavell 1987). This effect could be alleviated if (international) re-insurers pooled the risks facing different (national) insurers.

Insuring damages from climate change also raises moral hazard problems. ${ }^{10}$ Take the case of insurance against building damages from a storm: It may very well lead to less careful construction work and insufficient protection. Similarly, someone may be encouraged by the prospect of government support to buy a house near the coast taking an unnecessary risk of flood damage. The examples show, however, that the degree of moral hazard will depend on the willingness or ability of the insurance company to gather information. In principle it is free too control the construction or the site of a building and incorporate the information in the insurance contract. However, at least in some

\footnotetext{
${ }^{10}$ As has been discussed by Wildasin (2007) and Goodspeed et al. (2007) in the context of recent US hurricane events, the amount of autonomous adaptation to some climate change-related events may be lower if there is a perception that ex-post, the government will reimburse economic agents for much of the damages arising from such events. Even with the recognition that there may no full compensation, the ex-ante precaution might not reach the efficient level.
} 
cases the individual risk evaluation may prove to be too costly and the company will offer standard contracts with partial coverage only. The incident of moral hazard can also arise from public intervention: Many natural hazards have shown that politicians as well as the private sector provide financial aids for victims. The effort to help the victims of natural disasters is an act of emergency and humanity. As in the case of private insurance anticipation of loss compensation by the government may lead to insufficient precaution and - as mentioned above - to crowding out of private insurance. Therefore, ex-post emergency relief should be limited to most elementary protection.

The underlying assumption of the argument is that potential victims have complete information about expected damages and appropriate preventive measures. Most often this will not be the case with natural hazards. People are rather likely to underestimate and highly discount the full extent of the risk of rare events (Kunreuther 1996, Schwarze and Wagner 2006). The acquisition and distribution of information about risks could be spotted as task of governmental action, leading to an increase of the demand for insurance coverage. The moral hazard problem arising from anticipation of ex-post emergency relief may still lead to under-insurance. Mandatory insurance schemes are a possible solution to this dilemma. As opposed to emergency relief a mandatory insurance scheme would allow the insurance takers to calculate the amount of compensation expected and additionally would guarantee comprehensive demand for and supply of insurance coverage. The instrument of mandatory insurance is well known from other economic fields, such as public health (Breyer and Zweifel 2009, Colombo 2001). However, also in designing the insurance mandate the government has to trade-off likely insurance benefits and possible moral hazard costs which arise whenever private precaution against damages are influenced by the presence of insurance.

Apart from mandating insurance or providing general information on climate change risks the role of the government in insurance markets is one of control and enforcement of contracts. In developed countries, for example, governments set building standards to prevent dangerous and faulty construction work. Such legislation can be in some conflict with the freedom of consumer choice, but basic standards in construction work are a prerequisite for contracts between a building company and its client, defining quality standards of construction work. Building standards are relevant for insurance markets, too: They create a level field for insurance by making more explicit likely risks associated with buildings.

Finally, depending on the national circumstances there may be the responsibility of a government to act as insurer of last resort in case of extreme weather events and to ensure affordable adaptation for low-income households. The fiscal effects will depend on the design of the implemented natural 
disaster insurance scheme and the role of the government in this scheme. Given the available information on damage estimates the necessary funds for the former may be considerable. These effects will presumably increase over time (i) because temperature and therefore the frequency and severity of natural disasters will increase and (ii) because of increasing wealth, population changes, and changes in settlement behavior. If the insurance density is low the state has to been prepared to compensate victims for losses caused by natural forces. The financial aid may withdraw important public investments. In contrast, if the insurance scheme is designed in a way that the density is high, many natural hazards can be compensated without government intervention. In this case public emergency relief would be necessary only if damage costs exceed the capacity of insurers and re-insures. That is state participation is strictly limited to cover the mega-damages. It is important to note that not only the need of state intervention but also damage costs can be expected to be lower in case of high insurance density because appropriately designed insurance policies induce potential victims to take preventive measures.

\subsection{Equity aspects}

Another possible justification for government intervention in the field of adaptation is equity. With respect to adaptation, equity issues may arise within countries, between EU member states, and between industrialized countries and developing countries. As explained in the preceding subsections, private (respectively regional) adaptation may be efficient in many areas, but it need not be considered as just (Mendelsohn 2000). This argument seems especially powerful in the international context of climate change: While developed countries bear the main responsibility for the strong increase in $\mathrm{CO}_{2}$ emissions during the last century, climate change damages are expected to be higher for developing countries where the adaptive capacity is relatively low (Parry et al. 2005, Goklany 2007). ${ }^{11}$

However, this is essentially a topic of development economics. In our contribution we focus on adaptation in the national context. Here, both vertical and horizontal equity (Atkinson and Stiglitz 1980) matter for public policy, i.e. aspects of redistribution between high and low income house-

\footnotetext{
${ }^{11}$ While G8 countries are responsible for approximately half of the world's cumulated $\mathrm{CO}_{2}$ emissions between 1850 and 2000 (WRI 2009), G5 countries, i.e. China, India, South Africa, Brazil, and Mexico, represent only a fraction of $9.6 \%$. In terms of individual countries, the largest emitters are the USA (23.6\% of the world's cumulated emissions), the EU-25 (21.6\%), Russia (6.6 \%) and Germany (6.0\%). China which recently became the world's largest $\mathrm{CO}_{2}$ emitter (MNP, 2008) is only responsible for a fraction of $5.7 \%$ of the world's cumulated $\mathrm{CO}_{2}$ emissions.
} 
holds and the equal treatment of individuals by the law. With respect to vertical equity low-income households may not be able to afford adaptation measures and equity concerns may thus motivate the need for governmental action. The intense debate about the introduction of lower energy prices for fuel- or energy-poor households ${ }^{12}$ in order to protect these households against adverse effects is an example for this kind of distributional problem. In the future, there may be a similar discussion about the "right” prices for adaptation measures or prices for inputs for such measures. Essentially, society has to decide which human needs it considers to be elementary and deserve insurance by public authorities if a citizen cannot provide for himself. Adaptation may require new answers to this old question of social policy. Economic policy has to find measures to ensure these entitlements without excessive efficiency losses. In principle, the preferable solution from an economist's viewpoint is to give lump-sum transfers to low-income households. Thereby relative prices will not be distorted and the governmental support is transparent. The case of health insurance shows, though, that in some cases satisfying entitlements may require more complex answers, in particular when moral hazard and adverse selection render first-best solutions impossible. These can arise in the case of energy poverty, too: Poor households tend to live in rented rather than self-owned homes and will thus have little influence on the insulation. Real estate companies, on their part, will rather not invest into insulation when they cannot charge higher rents. This may justify government handling of social housing.

The matter of horizontal equity may well prove to be trickier. As discussed in the section on public goods, it may well be efficient to shelter one agglomeration from flooding while giving up another agglomeration, depending on the relative costs and benefits. Clearly, however, such a policy decision has very different impacts on real estate property rights. If taken by a central government, the unequal treatment would surely provoke lawsuits. In the future governments will have to develop rules (and limits) for compensation for households whose property is not protected. Federal states will have to device a framework of local, regional and national responsibilities for adaptation. Given the huge fiscal consequence of both collective adaptation and compensation, this is a great challenge.

\footnotetext{
12 See for example “Barroso urges lower energy prices to help poor”, July 6th 2008, http://www.eubusiness.com/newseu.
} 


\subsection{Security of Supply}

Security of supply is one of the stated goals of energy policy in EU and US law (e.g. COM 2009a, HR 2007). While mostly discussed in relation to energy, arguments of security of supply are also directly or indirectly - used in debates on food and water supply. All these sectors face considerable challenges by climate change, and thus security of supply matters for the debate of adaptation, too. From a theoretical economic perspective, the issue is odd at first sight: energy carriers, food and water are private goods in the economic sense of the word, and efficiency of markets in their provision should be guaranteed by the basic welfare theorems of economics. In the case of energy and water, transport provides an economic argument for government intervention: Electricity grids, gas pipelines and water sewage systems are typical examples of natural monopolies: Their provision of the transport service is characterized by increasing returns to scale, i.e. the larger the network, the lower per-unit costs of transport (this is also called a network externality). Therefore competition between several providers of transport service is inefficient because one single network can provide the service at lower cost. This gives an economic rationale for network regulation, since a monopolistic provider is likely to overcharge his service. However, the argument for government intervention on grounds of security of supply goes beyond regulation of networks. Rather it is based on the presumption that the good in question is indispensable for economic production and individual welfare: Indeed a prolonged shortage of drinking water in a certain region would have devastating effects on public health. ${ }^{13}$ Similarly, albeit to a lesser extent, public welfare and economic production are vulnerable to blackouts of the electricity system. The policy issue arises because companies providing water or energy in a free market are not likely to insure their consumers sufficiently against interruption of the supply: Given the short-term inelastic demand for the goods, markets are likely to clear at very high prices in case of a shortage - an efficient outcome, but unacceptable from a viewpoint of public welfare at least for some basic human needs. Private supply of drinking water is likely to be profitable during a drought period, but - given the elementary needs of the population - the government's objective would be to ensure that there are sufficient provisions for such a situation. ${ }^{14}$ The same reasoning applies to the energy sector, where secu-

\footnotetext{
${ }^{13}$ Northern China is an example - contamination of surface water and desertification endangers the drinking water supply and consequently the health of the population, in particular, rural areas (World Bank 2007). This is widely perceived as a public policy issue, both in China and outside.

${ }^{14}$ While water is certainly not a public good - its consumption is rival - economists refer to it as a common-pool resource, justifying regulation on grounds of negative external effects (McGuiness 1999, Hardin 1968). Given the basic need for drinking water, the regulation of water supply may in practice be governed by both efficiency and equity concerns.
} 
rity of supply is viewed as an important pillar of energy policy (Helm 2002, Abbott 2001). This does not imply, though, that the provision of the good has to be organized by public authorities: In the case of liberalized electricity markets, in many countries the grid is operated by a private monopolist that is regulated by a public agency. In particular, the grid company is obliged by law to ensure the security of the network, i.e. the security of electricity supply. The costs are incorporated into the usage fees. In other words: Specific regulation can be used to enforce security of supply in otherwise free markets, carefully trading off security against efficiency. Apart from problems to be discussed in a national context, security of supply can be a geopolitical issue: the supply of gas from gas-exporting countries with a monopolistic position may lead to political pressure on the importing countries. Similarly, in some world regions access to drinking water is seen as a right enforceable by political and - if necessary - military means. However, this problem is beyond an economic welfare analysis, because any market rule or property right in this context is vulnerable to political manipulation. Economists may contribute to a positive analysis of these aspects of adaptation to climate change by the study of international negotiations. These may e.g. arise in the context of access to scarce water resources or agricultural land with disputed property rights.

As in the case of equity issues, adaptation to climate change sheds a new light on old questions of security of supply: Which goods and services are elementary, so that government intervention should guarantee their security of supply? What are the costs of such a policy? What is an acceptable level of security of supply, e.g. in the case of drinking water? Public policy on adaptation will have to find answers to these questions.

\section{Climate change and economic policy in Germany}

In the sequel we apply the theoretical framework developed in section 2 to the case of adaptation in Germany. We focus on four climate-sensitive sectors and relevant fields of action, namely agriculture, energy, water and coastal protection, and public health. First, we describe the impacts of climate change in the absence of adaptation, in order to clarify specific adaptation needs. Second, we analyze optimal adaptation responses using the theoretical framework of section 2.

\subsection{Impacts on agriculture}

Agriculture accounts for a relatively small share of German GDP (0.7\% in 2006, Statistisches Bundesamt 2009). Nevertheless, an analysis of the agriculture sector makes sense since it is one of 
the most exposed to climate change. At the same time, the impacts of climate change on agriculture in Germany are in part detrimental and in part beneficial.

As for the benefits, in terms of yields positive effects are to be expected, due to the rising mean temperature and the resulting elongation of the vegetation period. Each sort of plants and trees has a temperature, where the growth capacity under otherwise optimal conditions is the highest. For example, the optimal temperature for corn lies between $25^{\circ} \mathrm{C}$ and $30^{\circ} \mathrm{C}$, for potatoes between $15^{\circ} \mathrm{C}$ and $20^{\circ} \mathrm{C}$ respectively (Chmielewski 2007). That is, where current mean temperatures are under the optimal temperature of certain plants, there are potentials of a higher yield due to a rising mean temperature. As for the elongation of the vegetation period, the number of days per year, when temperature allows for plant growth, is expected to rise significantly by up to 100 days in North Germany (2071/2100 compared to 1961/1990, Chmielewski 2007). That potentially gives the farmers the opportunity of additional sowings. Moreover, a higher $\mathrm{CO}_{2}$ ratio in the atmosphere may be beneficial for plant growth. From the pre-industrial level of $280 \mathrm{ppm}$, the $\mathrm{CO}_{2}$ ratio has already reached the current level of 380 ppm; and by 2100 the IPCC estimates an increase of atmospheric $\mathrm{CO}_{2}$ up to $700-1000$ ppm (IPCC 2007a), depending on mitigation efforts. Plants need $\mathrm{CO}_{2}$ for photosynthesis, and for most plants a $\mathrm{CO}_{2}$ ratio above $380 \mathrm{ppm}$ would increase the growth potential, in particular for $\mathrm{C}_{3}$-plant types (e.g. wheat and sugar-beet) which are predominant in Germany. $\mathrm{C}_{4}$-plants like maize and sorghum do not profit so strongly from a higher $\mathrm{CO}_{2}$ ratio as they use $\mathrm{CO}_{2}$ more efficiently and have almost reached their optimal $\mathrm{CO}_{2}$ usage today (Chmielewski 2007). However, the impact of this effect is controversial since it only holds under otherwise optimal conditions, in particular nutrient and water supply.

As for the cost of climate change, the potential benefits due to higher yields are partly and regionally offset by negative climate-induced impacts. Probably, the most severe negative effect will result from increasing climate variance and probability of extreme weather events. One single event of hail, heavy rainfall or a long drought period in summer can do more harm to yields than otherwise favorable weather conditions can make good. Especially for Eastern Germany one can expect severe consequences of drought periods as already today the hydrological balance ${ }^{15}$ is negative in great parts of this region. Furthermore, day temperatures above the plant-specific optimum have considerable negative effects on plant growth rates during these days (Schlenker and Roberts 2008). If it occurs, this negative effect of day temperatures above the optimum is stronger than

\footnotetext{
15 The hydrological balance means the difference of precipitation and potential surface evapotranspiration.
} 
positive impact of moderately warming day temperatures below the optimum. Thus slight improvements in output potential by beneficial average environment conditions are accompanied by severe adverse effects from more frequent extreme weather events and reduced predictability. Other negative effects are the immigration and increased occurrence of vermin and diseases, like the bluetongue-disease or the European corn borer (Chmielewski 2007, Wittmann and Baylis 2000).

Beside these supply side effects, there may be economically beneficial effects (for Germany) from developments at the demand side. As Parry et al. (2004) point out, global food production under various IPCC scenarios is likely to be negatively influenced by climate change (for 2080 projections of climate change impact on global food production vary between $+1 \%$ and $-5 \%$ ). The impact on global cereal prices has a positive sign in all scenarios and varies between $+7 \%$ and $+20 \%$ in 2080 under the assumption of a fully operative $\mathrm{CO}_{2}$ fertilization effect. Neglecting the relatively uncertain $\mathrm{CO}_{2}$ effect would result in even higher price increases (+50\% to $\left.+370 \%\right)$. At the same time, producers in developed countries like Germany benefit from higher prices, as their relative productivity rises as well. ${ }^{16}$

\subsection{Adaptation in Agriculture}

From a historical perspective, the agriculture sector has a long experience with adaptation to changing environmental conditions. As long as it exists, farmers have experimented with their crops and cultivation methods to adapt optimally to their respective climate regimes. Autonomous adaptation measures to the current climate change are the change of cultivated plants to more thermophile and drought resistant sorts, research and development of new crops ${ }^{17}$, investments in irrigation systems, the increased use of plant protection, and the use of private insurance against extreme weather events.

However, given the high level of regulation and state interference in the European agriculture sector one cannot discuss private adaptation measures leaving policy completely out of the picture. Following the argument in section 2.1 efficient state-planned adaptation includes setting a legal framework for water usage, chemical plant protection and research and development. State intervention in these cases is necessary due to (positive and negative) externalities of autonomous adap-

\footnotetext{
${ }^{16}$ Comparable results are also to be found in other studies (Fischer et al. 1994, Rosenzweig et al. 1994, Julia et al. 2007).

${ }^{17}$ Here also the genetic engineering may play a role such that crops are modified to be resistant to vermin, pests, diseases or chemical plant protection (Rosenzweig et al. 2000).
} 
tation measures. Furthermore, the government has a role as provider of public goods, as it promotes the production and distribution of information on region-specific climate change and thereby facilitates on the planning of climate-adapted planting and cultivation portfolios. Another essential task of the state is ensuring a functioning institutional framework for crop yield insurance, which includes regulation of financial markets and property rights. These activities can also be interpreted as a provision of public goods by the government. However, market failure alone has little explanatory power for the extensive agriculture policy which is presently pursued in Europe and which also influences adaptation processes. Security of food supply and equity aspects as presented in sections 2.4 and 2.5 are also important arguments for the Common Agriculture Policy (CAP) of the EU and consequently for adaptation policy in the agriculture sector. Thus a purely economic perspective of public intervention in adaptation would not give a realistic picture of the current state of affairs in European agriculture.

As an example for such government interventions we highlight public interference in the agricultural insurance market observable in some EU countries. Publicly financed subsidies of crop yield insurance premiums play an important role in countries like Portugal, Spain, France and Austria (von Alten 2008, Prettenthaler et al. 2006). In contrast, to date the focus in Germany is more on adhoc liquidity aid in the case of extreme weather events (Prettenthaler et al. 2006). These ad-hoc reliefs effectively have redistributional character, since they support the weak firms which would otherwise not survive after extreme weather events, like the long drought period in summer 2003. As discussed in section 2.3, there is an inherent moral hazard problem with this type of aid - it creates expectations, based on experiences of past events. The potential beneficiaries may be tempted to renounce costly protection or private insurance. However, they can not be completely sure whether and to which extent aids will be granted. Thus, a promotive framework of crop insurance in Germany would need more stipulated and credible regulations with regard to ad-hoc state relief to reduce uncertainty. ${ }^{18}$

One possible solution may be a recent approach of the Bavarian state government for natural hazard insurances for private homes (Bayerische Staatsregierung 2009). The government of this federal state in South Germany currently runs an information campaign in order to sensitize private households to the risks of natural hazard damages on homes and contents. Effectively, this campaign is a

\footnotetext{
${ }^{18}$ This line of reasoning is based on the argument for "rules rather than discretion" by Kydland and Prescott (1977), which is well-known to economists. The authors propose credible rules in order to avoid time-inconsistency of public policy.
} 
publicly financed marketing campaign for private insurance. In this context the government emphasizes that state relief is only possible in exceptional cases where private insurance is not applicable (less than $2 \%$ of Bavarian private households). Although this specific approach of the Bavarian state government targets only the market of insurance for private homes, a comparable strategy may also hold for government intervention in the market for crop yield insurances.

To sum up, most adaptation measures in the German agricultural sector are of private nature, and they are not restricted to the prevention of damages or the reduction of climate change costs, but they also encompass the reaping of potential benefits that a warming temperature provides. From an economic viewpoint collective adaptation consists of the provision of information and setting the framework for autonomous adaptation. However, security of food supply may lead to additional government intervention. Moreover, agricultural policy is prone to pressure by particular interest groups - a problem which may arise in adaptation policy as well. For example, ad-hoc state intervention in the case of extreme weather events, usually politically motivated, tends to have adverse effects on the efficient autonomous risk taking behavior.

\subsection{Impacts on the energy sector}

The energy supply sector accounts for $2.0 \%$ of German GDP (Statistisches Bundesamt 2009). The main impacts of climate change are related to the water reliance of many power plants. Watercooled heat power plants, such as nuclear and coal plants, are dependent on a steady supply of sufficiently cool river water. Due to rising temperatures and less precipitation in summer, there are high risks of insufficient and over-heated river runoffs. ${ }^{19}$ The consequences of endured drought periods are a forced reduction of power supply, a challenge for the planning of a reliable energy system. Though these problems are not expected to occur regularly, a secure energy supply will become more expensive. Power plants that are independent of water-cooling techniques are less cost-efficient. The same reasoning applies to hydro-power: long dry periods may cause severe supply shortages due low water levels. Therefore hydropower is unlikely to offer a reliable back-up for water-cooled production (Kropp et al. 2009).

\footnotetext{
${ }^{19}$ In a recent survey of ZEW $74 \%$ of the interviewed energy experts expect a higher frequency of power plant shutdowns due to global warming in the next $30-40$ years (ZEW 2009). Power plants most at risk of forced shut-down are nuclear and coal power plants, which contribute significantly to the steady power load.
} 
Water availability also affects energy supply by way of the dependency of water transport of coal power plants. Between 2004 and 2008, almost one half of the imported coal was transported to Germany via inland waterways, indicating the importance of waterways for the raw material supply of coal power plants (VDKI 2009, VDKI 2006). The supply of the energy carrier (mainly hard coal) via domestic waterways is endangered by high variations of the water level, as projected by future climate models. Floodings in winter after extreme rainfalls as well as too low levels in summer may challenge the input management of power plants and possibly lead to shortages in raw material supply.

Apart from supply-side effects, climate change is likely to induce demand side effects in the energy sector: Patterns of consumer behavior are bound to change with demand for heating in winter decreasing and demand for cooling in summer may increasing. The net effect on total energy demand is not clear by now, but it will obviously pose new challenges to the seasonal optimal load management.

\subsection{Adaptation in the energy sector}

Until 2030 more than $50 \%$ of the existing power plant capacity will be replaced by new plants (BMU and BMWi 2006). It can be expected that adaptation measures will be accounted for in the planning processes of new plants. As explained above this is in particular relevant for cooling systems and raw material supply. In the long run, power suppliers will have to develop strategies to cope with higher temperatures of cooling water, which may make increased research and development efforts in new cooling technologies necessary. Public adaptation policy here becomes relevant with regard to the funding of basic research and development, which has strong public goods properties. Besides, concerning the discharge temperature of used cooling water, environmental regulation is necessary to limit detrimental external effects on the river ecosystems. In that matter the balancing between environmental protection and a secure power supply becomes more important, as it was observable in the heat period of 2003, when exceptional governmental directives allowed discharge temperatures above the thresholds to preserve the security of power supply in Germany (Hauff and Kluth 2006). With regard to domestic waterways it is important to remember that - as part of traffic infrastructure - they have the character of a public good and therefore public policy should contribute to a solution to likely transport problems arising in draught periods.

Regarding the infrastructure of power distribution, it should be recalled that power failures cause considerable economic costs in industries and private households. Private providers of grid services 
are likely to take economic losses of supply failure insufficiently into account, as they face no competition and suffer only the temporary losses of grid fees. Regulators have to set the incentives right to ensure the investment into climate-proof infrastructure. In Germany, the Bundesnetzagentur has the duty to monitor network companies that have a legal obligation to ensure the safety of their grids, according to the argument developed in section 2.5 .

As explained above, at the demand side, there will be a shift from heating to cooling energy as a result of warmer temperatures. This has consequences for the structure of energy supply. There is empirical evidence concerning the implications for different energy carriers: De Cian et al. (2007) estimate temperature elasticities of demand for different countries. For most European countries (including Germany) the temperature elasticity of demand for electricity is positive while it is negative for gas and oil. Power producers will have to adapt to these altering usage patterns e.g. by increasing the peak-load capacity according to the demand in summer. These adaptation processes should be totally autonomous given the publicly available information on regional climate change impacts.

Thus, presumably most of the needed adaptation activities in the energy sector will be of autonomous nature, as anticipated also in the German Adaptation Strategy (Bundesregierung 2008). However, there are good reasons for a limited state intervention on grounds of security of supply, in funding of research and development and in the regulation of networks. Moreover, even neglecting mitigation effects, an increase of energy retail prices seems very likely due to adverse climate impacts on production costs. This is likely to create new challenges for energy policy - ensuring access to basic energy services to the poor. The phenomenon of "energy poverty" is by no means limited to the developing world. It has been a topic of an intensive public debate in the UK that has led to government programs providing fuel subsidies for poor and elderly people (BERR 2007) Other countries in the EU have started discussing the problem (EPEE 2008). As explained in section 2.4, an efficient answer to this challenge by public policy requires a definition of basic energy needs and a study of cost-efficient measures to achieve them.

\subsection{Impacts on water and coastal protection}

There are major challenges arising from climate change for water and coastal protection: (i) the water balance in summer, (ii) the increased risk of inland flood events, and (iii) sea level rise and storm surges. These different fields of action are related to different actors of the national economy. In Germany, the ground water balance affects mainly local state actors, like communities. Inland 
floods challenge authorities on the federal state level as well as private actors, whereas coastal protection clearly is a public issue.

Regarding water balance in summer, one has to notice the increasing risks of long drought periods as well as the general trend of less mean precipitation in summer months. The combination of both effects may eventually lead to local and temporary shortages in ground water supply and decreased river runoffs in summer. This, in turn, could give rise to water pollution, since low water levels tend to increase the concentration of solids or other harming substances and warm temperatures may cause algal blooms. Due to the cross-sectional characteristic of the water sector, many waterdependent economic sectors would be negatively influenced by water shortages and quality constraints. Not only agriculture and energy, but also transport and tourism ${ }^{20}$ would suffer from limited clean water availability. In contrast, apart from locally and temporarily limited events, drinking water safety is not considered to be endangered in Germany (Leibundgut and Kern 2006, UBA 2005). One reason is the fact that most of the drinking water supply is fed by groundwater sources and not by surface water (Bundesregierung 2008). Another reason is the strong decline in drinking water consumption in Eastern Germany after 1990, which results in significant capacities of drinking water infrastructure lying idle in these parts of Germany which are also particularly vulnerable to water scarcity according to climate projections (Komar 1999, UBA 2005).

The risk of inland floods has increased in the last decades above its natural variation margins (Bartels et al. 2005) and is expected to increase further. The reasons are an increased probability of stark rainfalls and a higher mean precipitation in winter which change the discharge regimes of rivers. However, other reasons for inland floods may loose relevance, as snow melting runoff might decrease as well as river floods due to ice floe (Eisenreich 2005, Bronstert 1996).

Probably the most widely known impact of climate change is the sea level rise. Projections of the climate-induced sea level rise vary between $18 \mathrm{~cm}$ and $59 \mathrm{~cm}$ by 2100 (IPCC 2007a chapter 10, lower bound of scenario B1 and upper bound of scenario A1FI). There are, however, also modeling approaches which estimate a sea level rise of more than $1 \mathrm{~m}$ by 2100 (Rahmstorf 2007, upper bound of scenario A1FI). These considerable discrepancies demonstrate the scientific challenges in estimating future sea levels, since they depend on temperature, windiness ${ }^{21}$, thermal water expansion, and the interactions of these and other hardly predictable variables. Difficulties in predicting

\footnotetext{
${ }^{20}$ Touristic lakeland areas may lose attractiveness if the water quality is harmed by to little influx (Dietrich 2004).

${ }^{21}$ According to IPCC (2007a) chapter 5, wind alone can cause changes in steric (not global) sea level.
} 
future windiness and resulting uncertainty about storm surges exacerbate the knowledge gaps on future threats from sea level rise (von Storch et al. 2007). Furthermore, in Germany geological downwards drifts of the coastal land of $1,5 \mathrm{~mm}-2,5 \mathrm{~mm}$ per year add to the projected sea level rise (Sterr 2007). Due to these geological and physical complexities, all predictions of sea level rise are subject to severe uncertainty. Though exact predictions of socio-economic impacts thereby are difficult, Germany is classified as highly sensitive in respect to sea level rise (Tol et al. 2008), since the topography, the population density, and the sensitive ecosystem in coastal areas contribute to high risks of a sea level rise (Sterr 2007). On a global scale, Hamburg belongs to the top 20 cities most exposed to sea level rise in terms of exposed asset accumulation (Nicholls et al. 2007). The study estimates the population in the exposed area in Hamburg to be 261,000 people and exposed assets in the order of 40 bn USD. According to Nicholls et al. (2007), by the 2070's the assets at risk can amount up to more than 120 bn USD, which will rank, however, not any more in the top 20.

\subsection{Adaptation in water and coastal protection}

Many of the government responses to scarce water supply in summer can be reasoned by the rationale of a secure supply, particularly with regard to drinking water. For example, local governments may increase the monitoring of water quality, regulate more strictly the private withdrawal from public waters, and invest in additional water supply infrastructure. ${ }^{22}$ Beside the security of supply argument state intervention can be rationalized by the network character of water supply and thereby by the provision of an imperfect public good as mentioned in section 2.1. Moreover, as an example for a pure public good, governments are supporting the dissemination of information on efficient water use and irrigation. Autonomous adaptation mainly consists of the adjustment of water consumption behavior to this information. Thus, autonomous adaptation plays a rather minor role here.

Concerning inland floods, an important autonomous adaptation measure is the use of insurance. Since 1994, flood risks can be insured by private households and companies within an insurance against natural hazards (in Eastern Germany even before 1994, as respective regulations of the former government continued). However, the insurance of extreme flood events poses a serious chal-

\footnotetext{
${ }^{22}$ In Eastern Germany these investments are expected to be limited for reasons explained in the preceding section.
} 
lenge for insurance companies; free markets often fail in providing an insurance protection for extreme events. As described in section 2.3 one important reason for that market failure is that the basing law of large numbers does not apply for extremely rare and costly events. Another reason why demand for natural hazard coverage is relatively low is the high discounting and underestimation of rare events (myopic behavior). Finally, the expectations of ad-hoc relief by the state hamper demand for insurance as in the case of crop yield insurance in agriculture. As a result, the reluctance of contracting insurance can cause a break-down in existing insurance markets, since demand is too low to sufficiently outweigh adverse selection effects and consequently premiums are quite high. On that account a mandatory natural hazard insurance scheme as presented in section 2.3 has been suggested for Germany (Schwarze and Wagner 2003). By now this scheme could not be realized mainly due to over-valued premiums and deductibles. So there is still a high probability of politically motivated ad-hoc emergency aid with the mentioned adverse effects on willingness to pay for autonomous adaptation measures.

In the sense of an efficient solution presented in the theory part of this paper the state should increase the awareness of risks in flood-prone areas and at the same time credibly make clear that adhoc relief measures are just to ease the most extreme hardships. These measures in combination could facilitate a functioning insurance market which would result in efficient autonomous adaptation and presumably lower insurance premiums. The approach of the Bavarian state government mentioned above (Bayerische Staatsregierung 2009) may serve as a first example of such a market oriented strategy, since it does not interfere into relative prices and is restricted to information and sensitisation of private households. In particular, the announcement of no state relief for insurable households is essential for functioning markets. However, it is questionable whether the government can credibly announce to deny any emergency relief above mere subsistence (e.g. due to political economy rationales). Moreover, beside government intervention there are also possible expectations of considerable private donations which could have adverse effects on private adaptation decisions. These effects are hardly predictable and not avoidable. Taking this into account, further instruments with a higher degree of intervention such as mandatory insurance may be appropriate.

Another government intervention mentioned in the German Adaptation Strategy is the adaptation of construction guidelines and regulations, such that new constructions in flood-endangered areas must be constructed in a flood-resistant manner (Bundesregierung 2008). To some extent a regulation of private building is indispensable (examples are given in section 2.3). But considering that flood-resistant building on the household-level protects only home-owners and has no significant 
impacts on the neighbors or the public, external effects are of minor importance. Thus, given sufficient information and risk awareness there is no market failure in the construction sector with regard to flood adaptation; and private agents would not need to be ordered to adapt.

Regarding these autonomous adaptation activities related to floods, the crowding-out effect by collective adaptation has also to be taken into account. In some cases public flood protection barriers may be effective, but private adaptation like flood-adapted building, insurance or retreat might cause lower costs. Then in the case of public investment in flood protection autonomous adaptation would be crowded out by collective adaptation and the economically second best solution would be the outcome (section 2.1).

Coastal protection is another important field of government action. Coastal protection infrastructures such as dykes have always been the prime example for a local public good. Other adaptation measures in regard to coastal protection are soft protection measures like revitalization and protection of natural flooding barriers, monitoring of the tides, and adapted spatial planning. Applying the paradigm of public goods, one concludes these measures fall into government's responsibility. In Germany the federal states are in charge of planning and financing coastal protection, whereas the federal government only assists in funding of initial investments. This is broadly in line with the theory of fiscal federalism mentioned in section 2.1 (Oates 1999) that places the financial and operational responsibility for a local good at the local level. However, this assignment of decisionmaking authority also leads to a need of coordination and cooperation between government entities like neighboring states, such as Bremen and Lower-Saxony. The two states have a common coast at the North Sea and therefore have drafted and implemented a common coastal protection strategy (PRC 2009). As described in section 2.1, if cooperation fails due to a conflict of interest between the two regions the central government has to step in to enforce a solution.

It is also worth mentioning that it may become economically reasonable to abandon some parts of land when the sea level rises further - a point developed in theory in section 2.1. In that case the question arises whether the state should abandon parts of the land and reimburse land owners who have relied on the guarantee of their ownership, manifested in public spatial planning; or to remain an economically expensive but politically desirable protection of the land. In that context spatial planning and building permissions become a very cost sensitive field of collective adaptation to climate change. Decisions today may cause high fiscal costs after several decades. 


\subsection{Impacts on public health}

Apart from its undisputed, yet hard to measure importance for human well-being, the German health sector accounted for 7.0 \% of GDP in 2007 (Statistisches Bundesamt 2009). Any normative economic analysis of public health poses tremendous challenges: Economic indicators alone like measurable costs and benefits or supply and demand can not reflect values associated with health in the society. We will get back to that issue later.

Talking about public health, demographic change has to be taken into account. In Germany, a significant ageing of the population is predicted by demographers. By 2050, the ratio of people older than 65 years will be between $30 \%$ and $36 \%$, compared to $19 \%$ in 2005 (Statistisches Bundesamt 2006). This will also have effects on the impacts of climate change, since this group is considered to be particularly climate-sensitive (Hübler et al. 2008).

Climate change impacts on human health can be divided into direct and indirect impacts. First, we will consider direct impacts like temperature-stress effects of cold days and heat days. Considering cold days, the warming climate is expected to contribute to a lower cold-related mortality. Heat days are expected to occur more often, especially in the South-West and in urban areas. Hübler et al. (2008) estimate a beneficial effect on the number of cold-casualties in the order of 3,000 lives, given the current demographic situation. Since elderly people also respond more sensitively to cold-stress, the positive effect can be up to 5,000 lives taking the expected demographic development into account. In contrast, the mortality due to high temperatures is expected to rise as a consequence of more frequent heat waves and hot days. Hübler et al. (2008) predict this adverse effect to be stronger than the beneficial effect (5,000 respectively 8,500 additional casualties, depending on accounting for the demographic factor). However, these results do not account for any adaptation to warmer temperature (e.g. housing, behavioral change), an assumption which is obviously not realistic. Other studies suggest much more positive net effects. Keatinge et al. (2000) assume natural and technical adaptation and expect an outweighing of additional heat mortality by much larger declines in cold related mortalities without quantification. Bosello et al. (2006) predict for the EU a decline in temperature-related mortality of 176,000 by 2050 . These discrepancies make clear that the connection between climate and human health is far from being fully understood and additional research is needed in this area.

Second, a number of indirect health effects of climate change are promoted by a warmer climate. Examples in Germany are allergies (caused by invasive thermophile plants and longer vegetation periods), vectors (in particular ticks which are expected to spread due to warmer temperatures), 
solar radiation, ${ }^{23}$ and possibly contaminations of drinking water (locally and temporarily limited, UBA 2005). However, there is still a lack of high quality epidemiological studies (e.g. concerning temperature effects on animal vectors), and the connection of climate and indirect health effects needs more research to be fully understood.

Regarding the monetary effects of climate change in human health, ethical issues become relevant. Questions about the monetary valuation of human life or a healthy life can not be assessed by economists alone. There are attempts to evaluate the economic costs of adverse health effects by hospitalization costs and macroeconomic productivity losses (Hübler et al. 2008), but the actual monetary valuation of human lives is beyond the scope of economic theory. Unfortunately, as an evaluation of alternative investments in health systems often means outbalancing different human lives, additional value judgments are needed. Some principles health economists adhere to are equality and productivity: Every human life can be valued equally, or there may be an adjustment to the expected remaining life years or to the age-specific mean productivity. In any case, for political decision-makers it is important to follow consistent and transparent rules and criteria for outbalancing of alternative investments in different health systems.

\subsection{Adaptation in public health}

Regardless of the real net effect of future temperature-related mortality, there is no dispute that adaptation is needed to limit or avoid adverse climate change effects on human health. Even if the avoided cold-related mortality were much higher than the additional heat-related mortality, casualties always urge for action to counteract them (Keatinge et al. 2000). Moreover, studies for cities in the USA suggest a high potential of effective adaptation activities. ${ }^{24}$

With regard to heat waves, the greatest part of adaptation responses is of autonomous nature. Given expectations of a warming climate, private households and firms may install air-conditioning or ventilation or plan new buildings in a manner that reduces indoor heat during summer. Housing is a private good and decisions are decentralized, the role of the government should be limited to con-

\footnotetext{
${ }^{23}$ Even if the solar radiation itself will not intensify due to climate change, individual behavior in warmer temperatures may be more promotive for skin cancer caused by solar radiation.

${ }^{24}$ Weisskopf et al. (2002) assess the health effects of two heat waves in Milwaukee, USA and come to the conclusion that differences in morbidity and mortality were not attributable to temperature differences alone, but also to improved health system preparedness and information policy. The effects of other impacts than temperature variation on mortality rates are estimated at a decrease by at least $49 \%$. Davis et al. (2003) observe a decline in heat-related mortality in different US cities and attribute this desensitization to a suite of technical, infrastructural, and biophysical adaptations.
} 
trol and enforcement of contracts (which may specify air conditioning as part of a renting agreement). At the most, government intervention is appropriate to provide for necessary information for renting agreements, as it is practiced already in Germany by the introduction of the compulsory energy performance certificate for buildings (EnEV 2007, Dena 2009). The existing regulation which focuses on the energy need for heating could easily be adapted in order to take into account the energy need for cooling. Focusing on the energy need for cooling has the advantage that several cooling techniques (air-conditioning, reducing building's albedo, water-based cooling etc.) could be considered in order to reduce the costs of cooling. This regulation would comprehensively tackle the information asymmetries in renting agreements and thereby allow for well-informed, autonomous market-led decisions. ${ }^{25}$ In contrast, local policy makers may be confronted with decisions regarding the allocation of scarce resources for technical adaptation to heat waves in publicly owned facilities (e.g. kindergartens, schools, nursing homes and hospitals). They have to confront a difficult ethical cost-benefit analysis, counterbalancing different aspects of human well-being given scarce funds. Economics can help by providing a consistent and transparent framework for decision-making, not, though, by providing definite answers. Akbari et al. (2009) analyze a relatively simple, but effective measure that home-owners can undertake to reduce heat effects - the albedoeffect of white-painted buildings and pavements. Furthermore, they found that sufficient white color in urban areas not only reduces high indoor temperatures but also contributes essentially to an abatement of urban warming. That is, it can be efficient to promote urban albedos since - in the case of private buildings - it is an autonomous adaptation measure with positive externalities. However, beside the technical feasibility of adaptation options (which is quite high for urban albedos) decision makers also have to take account of social and cultural feasibility which may become very relevant, e.g. in picturesque old towns. Other major state-run adaptation initiatives with regard to direct health effects are characterized by production and distribution of information (e.g. information on adverse health effects of heat), and the provision of monitoring and early-warning systems, which fall into the category provision of public goods.

Also the adaptation policy to indirect health effects encompasses information and monitoring systems. The government may communicate threats of diseases promoted by warmer climate, such as the tickborne encephalitis, the lyme borreliosis, or solar radiation; and give advices for protection

\footnotetext{
${ }^{25}$ Possible external effects of additional energy demand due to technical cooling responses (GHG-emissions of power production) are best off-set by a regulatory framework for emissions from electricity generation - for Germany that is the EU Emissions Trading System. The issue can therefore be discussed separately from adaptation.
} 
measures on the individual level. Most of the measures themselves clearly have the character of autonomous adaptation, e.g. the protection from solar radiation and ticks by long-sleeved clothes and adapted leisure behavior. An example of possible collective adaptation may be the elimination of invasive plants with allergenic effects on humans - a measure with clear positive externalities. To date the government runs information campaigns to sensitise private gardeners and farmers and to instruct them how to combat the ragweed plant, for example (BMU 2009, Julius-Kühn-Institut 2009). However, from an economic point of view a stronger government intervention will become appropriate if social costs due to allergies exceed the costs of a centrally planned intervention. ${ }^{26}$ Other adaptation measures are the education and training of medical staff with regard to prevention, diagnosis and treatment of diseases promoted by warmer climate and intensified vaccination programs (in particular against tickborne encephalitis). These activities do not accrue to the government itself (unless vaccination is necessary to avoid epidemic plagues, which is - at least to date not expected by climate change induced health effects), however they still affect the public sector through public health insurances.

In conclusion, adaptation to direct health effects like technical or behavioral responses to heat waves is predominantly autonomous; government intervention regarding heat is mainly constituted by information dissemination and investment decisions for public institutions. With regard to indirect health effects, there are also considerable public activities, given the public structure of great parts of the health system in Germany.

\section{Conclusions and outlook}

Since the prospects for an effective international agreement on climate policy with binding emission reduction targets are uncertain and climate change impacts are becoming increasingly visible today already, politicians and researchers attach more and more importance to the topic of adaptation to climate change. The economic analysis of adaptation, however, is still in infancy with a few economic studies covering specific aspects of adaptation. A notable exception is the contribution of de Bruin et al. (2009a), which includes different adaptation levels into the integrated assessment model DICE, thereby making the trade-off between mitigation and adaptation visible. In theory, this method can provide decision makers with necessary information on costs and benefits of adap-

\footnotetext{
${ }^{26}$ Social costs estimates for ragweed-induced diseases can be found in Reinhardt et al. (2003) and Gren et al. (2007).
} 
tation options, thus offering a sound economic and quantitative framework for adaptation policy. However, as Ackermann et al. (2009) point out, currently available integrated assessment models have important limitations. The authors refer to models analyzing climate damages with a focus on mitigation, but still their critique also applies to models including adaptation. Some of their important points of critique are the questionable assumptions regarding the rate of time preference, the speculative attempts of monetary assessment of human lives and ecosystems, and the downplaying of scientific uncertainty about the extent of expected damages. According to Ackermann et al. (2009 p. 304) the models are “[p]redicting the unpredictable and pricing the priceless". While this view is debatable, clearly, there is no doubt that the current models have restrictions limiting their predictive power for cost-benefit-analyses. A preliminary solution may be the multi-criteria analysis (de Bruin et al. 2009b). The approach takes into account various adaptation options and judgements of experts and stakeholders, and focuses not only on quantitative criteria, but due to data availability and estimation problems also includes qualitative criteria like Importance, Urgency, and No regret. Although this approach has its own limitations (of which some are raised by Füssel 2009), it serves as a useful method to assess the possibilities of adaptation policy for the intermediate stage as long as data and knowledge gaps limit a comprehensive cost-benefit analysis. Still, more quantitative studies on adaptation efforts are needed, in particular on the costs and benefits of measures in specific sectors such as energy or health and on the direct and indirect economic effects of adaptation efforts on the economic system.

This paper takes a more general view upon adaptation policy. It does not attempt to identify specific high-priority policy options, but rather analyses fields of action for policy makers and defines rationales and arguments for government intervention in adaptation processes. It aims at developing a broad economic framework for adaptation which can provide a foundation and starting point for future economic research. The perspective we take is the one of a sovereign state - not an international arena, where regulation is difficult to enforce. The economic framework allows us to distinguish between autonomous adaptation by private agents on the one hand and collective adaptation measures by governmental entities on the other. Our theoretical economic approach to adaptation encompasses the theory of market failures, such as public goods or externalities, real option theory, the theory of insurance markets including moral hazard and adverse selection. The theoretical section is completed by the consideration of more additional political objectives, namely equity and security of supply. Furthermore, any adaptation strategy has to supplement existing legislations. Hence, a normative and purely theoretical analysis is not sufficient but has to be accompanied by a positive analysis of current regulation. Nevertheless, cost-efficient solutions should always be the 
starting point of a discussion before taking alternative strategies - adapted to the reality of a specific problem - into considerations in order to identify and possibly limit efficiency losses that may come along with the pursuit of politically motivated objectives.

The efficiency-oriented approach developed in the theory part is then applied to the case of Germany. Due to its size and geography as well as its relatively diversified sectoral structure Germany is a good example for the analysis and development of adaptation measures in climate sensitive sectors in industrialized countries, particularly in Europe. The case study about Germany covers the sectors that are particularly vulnerable to climate change, namely agriculture, energy, water and coastal protection, and human health. Results indicate that in Germany a wide range of (positive and negative) impacts are to be expected which require differentiated adaptation strategies initiated at different levels of decision making. The case study is based on available literature about climate change and its economic impacts as well as adaptation measures implemented or planned in Germany.

In all sectors the provision and distribution of information about regional climate change impacts are central and necessary tasks of the government because public information is a classical public good whose provision creates considerable costs. The same holds true for the funding of basic research and development of new technologies which facilitate the adaptation to climate change. As the agriculture sector has a long-time experience with adaptation to changing environmental and climate conditions it probably will not have difficulties to autonomously adapt to further incremental climate change. In case of abrupt changes and extreme weather events, however, the availability and use of insurances becomes relevant and government intervention may be necessary if insurance markets do not lead to a reasonably efficient and politically acceptable outcome. Other government interventions are expected for the regulation of externalities caused by private adaptation measures such as the use of pesticide and herbicide or genetically modified crops. Similarly in the energy sector most adaptation measures can be expected to take place autonomously. State intervention therefore should be limited to the regulation of existing (environmental and network) externalities, the securing of energy supply and possibly energy poverty. In contrast to the agriculture and energy sector, in the field of water and coastal protection considerable state intervention is indispensable. The responsibility of the government comprises the provision of local public goods such as dykes and recreation areas, the adjustment of existing construction guidelines and settlement regulations, the consideration of vertical and horizontal equity aspects, and most important the establishment of a functioning insurance market. In the health sector both kind of adaptation, pri- 
vate and public, appear to be of importance. The installation of air-conditioning, the adjustment of building construction, and general behavior modification probably proceed autonomously. As opposed, the implementation of an early warning system, the regulation of immunizations, the education and training of medical staff, and the technical adaptation of publicly owned facilities require far reaching state interventions as they all are characterized by the existence of market failures and respond to political prerogatives of equal access to medical treatment.

The German National Adaptation Strategy which was published in December 2008 (BMU 2008) is rather vague and cautious regarding specific adaptation measures. It primarily focuses on the identification of vulnerable regions and sectors, the generation and distribution of information about regional climate change impacts, the delineation of available adaptation options, the extension of adaptation capacities, and the initiation of a public debate. Basically the same applies to the White Paper of the European Commission on adaptation which was published in April 2009 (COM 2009b). This cautious approach reflects the current lack of knowledge and missing consensus on a strategy how to respond to the great challenge of climate change. As time proceeds, however, the need for action becomes more pressing - and arguably moderate overinvestment or underinvestment in adaptation measures is preferable to inaction (Agrawala et al. 2009). As both official documents show, a coherent economic perspective on the topic is still missing. With this discussion paper, we hope to contribute to its development. 


\section{References}

Abbott, M. (2001), Is the Security of Electricity Supply a public good?, The Electricity Journal 14(7), 31-33.

Ackermann, F., S.J. DeCanio, R.B. Howarth, and K. Sheeran (2009), Limitations of integrated assessment models of climate change, Climatic Change 95, 297-315.

Agrawala, S., K. de Bruin, and R. Dellink (2009), Economic Aspects of Adaptation to Climate Change: Integrated Assessment Modelling of Adaptation Costs and Benefits, OECD Working Party on Global and Structural Policies.

Akbari, H., S. Menon, and A. Rosenfeld (2009), Global cooling: increasing world-wide urban albedos to offset $\mathrm{CO}_{2}$, Climatic Change 94(3), 275-286.

Anthoff, D., C. Hepburn, and R.S.J. Tol (2009), Equity weighting and the marginal damage costs of climate change, Ecological Economics 68(3), 836-849.

Arrow, K.J. (1963), Uncertainty and the Welfare Economics of Medical Care, American Economic Review 53(5), 941-973.

Atkinson, A.B. and J.E. Stiglitz (1980), Lectures on Public Economics, McGraw Hill, London.

Bator, F.M. (1958), The Anatomy of Market Failure, The Quarterly Journal of Economics 72(3), 351-379.

Bayerische Staatsregierung (2009), voraus denken - elementar versichern, http://www.elementarversichern.bayern.de/index.html, downloaded on 24.07.2009.

Berrittella, M., A. Bigano, R. Roson, and R.S.J. Tol (2006), A general equilibrium analysis of climate change impacts on tourism, Tourism Management 27(5), 913-924.

BMU and BMWi (2006), Energieversorgung in Deutschland. Statusbericht für den Energiegipfel am 3. April 2006, http://www.bmu.de/files/download/application/pdf/statusbericht_0603.pdf, downloaded on 02.12.2008.

BMU (2009), Hintergrundinformationen zu Naturschutz und Gesundheit, http://www.bmu.de/files/pdfs/allgemein/application/pdf/hg_naturschutz_gesundheit_bf.pdf, downloaded on 27.08.2009.

Bosello, F., R. Roson, and R.S.J. Tol (2006), Economy-wide estimates of the implications of climate change: Human health, Ecological Economics 58(3), 579-591.

Breyer, F. and P. Zweifel (2009), Health Economics, Springer, Berlin.

Bronstert, A. (1996), River flooding in Germany: influenced by climate change? Physics and Chemistry of the Earth 20(5-6), 445-450.

Bundesregierung (2008), Deutsche Anpassungsstrategie an den Klimawandel, http://www.bmu.de/klimaschutz/downloads/doc/42783.php, downloaded on 15.07.2009.

CEU (2004), Council of the European Union, 2632nd Council Meeting, Brussels, 20.12.2004.

Chmielewski, F.M. (2007), Folgen des Klimawandels für Land- und Forstwirtschaft, in: Endlicher, W. and F.W. Gerstengarbe (ed.), Der Klimawandel - Einblicke, Rückblicke und Ausblicke, Potsdam Institut für Klimafolgenforschung, Berlin, 75-85.

Colombo, F. (2001), Towards More Choice in Social Protection?: Individual Choice of Insurer in Basic Mandatory Health Insurance in Switzerland, OECD Working Paper 53/2001, Paris.

COM (2009a), Regulation of the European Parliament and of the Council concerning measures to safeguard security of gas supply and repealing Directive 2004/67/EC, Brussels, 16.7.2009 $\operatorname{COM}(2009) 363$ final.

COM (2009b), Adapting to climate change: Towards a European framework for action, White Paper of the Commission of the European Communities, Brussels, COM (2009) 147 final.

Davis, R.E., P.C. Knappenberger, P.J. Michaels, and W.M. Novicoff (2003), Changing HeatRelated Mortality in the United States, Environmental Health Perspectives 111(14), 1712- 
1718.

de Bruin, K.C., R.B. Dellink, and R.S.J. Tol (2009a), AD-DICE: an implementation of adaptation in the DICE model, Climatic Change 95, 63-81.

de Bruin, K.C., R.B. Dellink, A. Ruijs, L. Bolwidt, A. van Buuren, J. Graveland, R.S. de Groot, P.J. Kuikman, S. Reinhard, R.P. Roetter, V.C. Tassone, A. Verhagen, and E.C. van Ierland (2009b), Adapting to climate change in The Netherlands: an inventory of climate adaptation options and ranking of alternatives, Climatic Change 95, 23-45.

de Cian, E., E. Lanzi, and R. Roson (2007), The Impact of Temperature Change on Energy Demand. A Dynamic Panel Analysis, Working Papers 2007, 46, FEEM.

BERR (2007), Department for Business Enterprise \& Regulatory Reform, The UK Fuel Poverty Strategy $-5^{\text {th }}$ Annual Progress Report, London.

Deutscher Bundestag (1992), Erster Bericht der Enquete-Kommission „Schutz der Erdatmosphäre“ zum Thema Klimaänderung gefährdet globale Entwicklung - Zukunft sichern - Jetzt handeln, Bundesdrucksache 12/2400 vom 31.03.1992, Bonn.

Dena (2009), Energy Performance Certificates for Buildings. http://www.zukunfthaus.info/en/energy-certificate.html.

Dietrich, O. (2004), Spreewald - Das Integrationskonzept Spreewald und Ergebnisse zur Entwicklung des Wasserhaushalts, in: Integrierte Analyse der Auswirkungen des globalen Wandels auf Wasser, Umwelt und Gesellschaft im Elbeeinzugsgebiet - Schlussbericht zum Vorhaben GLOWA-Elbe I (Hrsg. F. Wechsung, A. Becker, and P. Gräfe). Potsdam Institut für Klimafolgenforschung, Potsdam.

Dixit, A. and S. Pindyk (1994), Investment under Uncertainty, Princeton University Press, NJ.

EEA (2008), Impacts of Europe's changing climate - 2008 indicator-based assessment, EEA Report No 4/2008, JRC Reference Report No JRC47756.

Eisenreich, S.J. (2005), Climate and the European water dimension. Joint Research Center, European Commision, Ispra.

EnEV (2007), Verordnung über energiesparenden Wärmeschutz und energiesparende Anlagentechnik bei Gebäuden (Energieeinsparverordnung - EnEV), vom 24. Juli 2007.

EPEE (2008), European project on fuel Poverty and Energy Efficiency, Diagnosis of causes and consequences of fuel poverty in Belgium, France, Italy, Spain and United Kingdom, compare www.fuel-poverty.org (09.02.2009).

Epstein, R. (1996), Catastrophic Responses to Catastrophic Risk, Journal of Risk and Uncertainty 12(2/3), 287-308.

Fankhauser, S. (2006), The Economics of Adaptation, EBRD, 12 April 2006.

Fischer, G., K. Frohberg, M.L. Parry, and C. Rosenzweig (1994), Climate change and world food supply, demand and trade - Who benefits, who loses?, Global Environmental Change 4(1), 7-23.

Füssel, H.M. (2009), Ranking of national-level adaptation options. An editorial comment, Climatic Change 95, 47-51.

Goklany, I.M. (2007), Integrated strategies to reduce vulnerability and advance adaptation, mitigation, and sustainable development, Mitigation and Adaptation Strategies for Global Change 12(5), 755-786.

Gollier, C. (2000), The Economics of Risk and Time, MIT Press, Cambridge (Mass).

Goodspeed, T.J. and A.F. Haughwout (2007), On the Optimal Design of Disaster Insurance in a Federation, CESifo Working Paper No. 1888.

Gren, I.-M., L. Isacs, and M. Carlsson (2007), Costs of Alien Invasive Species in Sweden, A Journal of the Human Environment 38(3), 135-140.

Hardin, G. (1968), The Tragedy of the Commons, Science 162(3859), 1243-1248.

Heal, G. and B. Kriström (2002), Uncertainty and Climate Change, Environmental and Resource Economics 22, 3-39. 
Helm, D. (2008), Climate-change policy: why has so little been achieved? Oxford Review of Economic Policy 24(2), 211-238.

Hildén, M., H. Lehtonen, I. Bärlund, K. Hakala, T. Kaukoranta, and S. Tattari (2005), The practice and process of adaptation in Finnish agriculture. FINADAPT Working Paper 5, Finnish Environment Institute Mimeographs 335, Helsinki.

HR (2007), House of Representatives, Energy Independence and Security Act of 2007, 110th Congress.

Hübler, M., G. Klepper, and S. Peterson (2008), Costs of Climate Change - The Effects of Rising Temperatures on Health and Productivity in Germany, Ecological Economics 68(1-2), 381393.

IPCC (2007a), Climate Change 2007: The Physical Science Basis. Contribution of Working Group I to the Fourth Assessment Report of the Intergovernmental Panel on Climate Change [Solomon, S., D. Qin, M. Manning, Z. Chen, M. Marquis, K.B. Averyt, M. Tignor and H.L. Miller (eds.)]. Cambridge University Press, Cambridge, United Kingdom and New York, NY, USA, 996 pp.

IPCC (2007b), Climate Change 2007: Impacts, Adaptation and Vulnerability. Contribution of Working Group II to the Fourth Assessment Report of the Intergovernmental Panel on Climate Change [Parry, M.L., O.F. Canziani, J.P. Palutikof, P.J. van der Linden and C.E. Hanson, Eds.]. Cambridge University Press, Cambridge, UK, 976 pp.

Julia, R. and F. Duchin (2007), World Trade as the Adjustment Mechanism of Agriculture to Climate Change, Climatic Change 82(3-4), 393-409.

Julius-Kühn-Institut (2009), Ambrosie, http://www.jki.bund.de/nn_1145390/DE/Home/pflanzengesundheit/schadorganismen/ambrosia/ambrosia_node.html_nnn=true, downloaded on 27.08.2009.

Keatinge, W.R., G.C. Donaldson, E. Cordioli, M. Martinelli, A.E. Kunst, J.P. Mackenbach, S. Nayha, and I. Vuori (2000), Heat related mortality in warm and cold regions of Europe: observational study, British Medical Journal 321(7262), 670-673.

Komar, W. (1999), Trinkwasserversorgung in Deutschland: wirksamer Grundwasserschutz notwendig, Wirtschaft im Wandel 2/1999.

Kropp, J., A. Holsten, T. Lissner, O. Roithmeier, F. Hattermann, S. Huang, J. Rock, F. Wechsung, A. Lüttger, S. Pompe, I. Kühn, L. Costa, M. Steinhäuser, C. Walther, K. Klaus, S. Ritchie, and M. Metzger (2009), Klimawandel in Nordrhein-Westfalen - Regionale Abschätzung der Anfälligkeit ausgewählter Sektoren, Abschlussbericht, http://www.umwelt.nrw.de/umwelt/klimawandel/index.php, downloaded on 16.07.2009.

Kunreuther, H. (1996), Mitigating Disaster Losses through Insurance, Journal of Risk and Uncertainty 12(2-3), 171-187.

Kydland, F.E. and E.C. Prescott (1977), Rules Rather than Discretion: The Inconsistency of Optimal Plans, Journal of Political Economy 85(3), 473-491.

Leibundgut, C. and F.-J. Kern (2006), Wasser in Deutschland - Mangel oder Überfluss?, Geografische Rundschau 58(2), 12-19.

Matzarakis, A. and B. Tinz (2008), Tourismus an der Küste sowie in Mittel- und Hochgebirge, in: J. Lozán et al., Warnsignal Klima: Gesundheitsrisiken. Gefahren für Menschen, Tiere und Pflanzen, Hamburg, 247-252.

McDonald, R. and D. Siegel (1986), The Value of Waiting to Invest, The Quarterly Journal of Economics 101(4), 707-728.

McGuiness, M. (1999), Polycentric governance and development, University of Michigan Press

Mendelsohn, R. (2000), Efficient Adaptation to Climate Change, Climatic Change 45(3-4), 583600.

MNP (2008), China contributing two thirds to increase in $\mathrm{CO}_{2}$ emissions, The Netherlands Environmental Assessment Agency (MNP), Press release, 13 June 2008. 
MPI (2008), Regionale Klimasimulationen für Deutschland, Österreich und die Schweiz, http://www.mpimet.mpg.de/en/wissenschaft/ueberblick/atmosphaere-imerdsystem/regionale-klimamodellierung/remo-uba.html.

Müller-Fürstenberger, G. and I. Schumacher (2008), The Economics of Insurance and Endogenous Extreme Events, Working Paper University of Trier, Germany.

Munich Re (2006), Topics Geo: Natural Catastrophes 2006: Analyses, Assessments, Positions, Munich Reinsurance Company.

Nicholls, R.J., S. Hanson, C. Herweijer, N. Patmore, S. Hallegatte, J. Corfee-Morlot, J. Château, and R. Muir-Wood (2007), Ranking Port Cities with high Exposure and Vulnerability to Climate Extremes - Exposure Estimates, Environment Working Papers No. 1, OECD.

Nordhaus, W.D. (1991), To slow or not to slow: the economics of the greenhouse effect, Economic Journal 101(6), 920-937.

Oates, W.E. (1999), An Essay on Fiscal federalism, Journal of economic Literature 37(3), 1120-49.

OECD (2008), Economic Aspects of Adaptation to Climate Change, OECD Publishing, Paris.

Parry, M.L., C. Rosenzweig, A. Iglesias, M. Livermore, and G. Fischer (2004), Effects of climate change on global food production under SRES emissions and socio-economic scenarios, Global Environmental Change 14(1), 53-67.

Parry, M.L, C. Rosenzweig, and M. Livermore (2005), Climate change, global food supply and risk of hunger, Philosophical Transactions of the Royal Society B 360, 2125-2136.

Pearce, D.W., W.R. Cline, A. Achanta, S. Fankhauser, R. Pachauri, R. Tol, and P. Vellinga (1996), The Social Costs of Climate Change: Greenhouse Damage and the Benefits of Control, in: Intergovernmental Panel on Climate Change, Climate Change 1995: Economic and Social Dimensions of Climate Change, Cambridge, Cambridge University Press, 183-224.

Pindyck, R.S. (1991), Irreversibility, Uncertainty, and Investment, Journal of Economic Literature 29(3), 1110-1148.

PRC (2009), Policy Research Corporation, The economics of climate change adaptation in EU coastal areas, Final Report for the European Commission.

Prettenthaler, F., S. Strametz, C. Töglhofer, and A. Türk (2006), Anpassungsstrategien gegen Trockenheit: Bewertung ökonomisch-finanzieller versus technischer Ansätze des Risikomanagements, Wissenschaftlicher Bericht Nr. 8-2006, Wegener Zentrum für Klima und Globalen Wandel Karl-Franzens-Universität Graz.

Rahmstorf, S. (2007), A Semi-Empirical Approach to Projecting Future Sea-Level Rise, Science 315(5810), 368-370.

Reinhardt, F., M. Herle, F. Bastiansen, and B. Streit (2003), Economic Impact of the Spread of Alien Species in Germany, Umweltbundesamt Research Report 20186211.

Rosenzweig, C. and M.L. Parry (1994), Potential impact of climate change on world food supply, Nature 367, 133-138.

Rosenzweig, C., A. Iglesias, X.B. Yang, P.R. Epstein and E. Chivian (2000), Climate Change and U.S. Agriculture: The Impacts of Warming and Extreme Weather Events on Productivity, Plant Diseases, and Pests, Centre for Heath and the Global Environment, Boston.

Rosenzweig, C. and F.N. Tubiello (2007), Adaptation and mitigation strategies in agriculture: an analysis of potential synergies, Mitigation and Adaptation Strategies for Global Change 12(5), 855-873.

Rothschild, M. and J. Stiglitz (1976), Equilibrium in Competitive Insurance Markets: An Essay on the Economics of Imperfect Information, The Quarterly Journal of Economics 90(4), 629649.

Samuelson, P. (1954), The pure theory of public expenditure. Review of Economics and Statistics 36(4), 387-389.

Schelling, T.C. (1992), Some Economics of Global Warming, The American Economic Review 82(1), 1-14. 
Schlenker, W. and M. Roberts (2008), Estimating the Impact of Climate Change on Crop Yields: The Importance of nonlinear Temperature Effects, NBER Working Paper 13799.

Schmidt, S., C. Kemfert and P. Höppe (2009), Tropical cyclone losses in the USA and the impact of climate change - A trend analysis based on data from a new approach to adjusting storm losses, Environmental Impact Assessment Review, in press 2009.

Schoemaker, P.J.H. (1982), The Expected Utility Model: Its Variants, Purposes, Evidence and Limitations, Journal of Economic Literature 20(2), 529-563.

Schönwiese, C.-D., T. Staeger, and S. Trömel (2005), Klimawandel und Extremereignisse in Deutschland, DWD (2005): Klimastatusbericht 2005, 7-17.

Schwarze, R. and G.G. Wagner (2003), Mandatory Insurance Against Natural Disasters: Why and How? Economic Bulletin Volume 40(5), 175-180.

Schwarze, R. and G.G. Wagner (2006), The Political Economy of Natural Disaster Insurance: Lessons from the Failure of a Proposed Compulsory Insurance Scheme in Germany, DIW Discussion Paper 620, Berlin.

Shavell, S. (1987), Economic Analysis of Accident Law, Havard University Press.

Statistisches Bundesamt (2006), 11. koordinierte Bevölkerungsvorausberechnung, Annahmen und Ergebnisse, Wiesbaden.

Statistisches Bundesamt (2009), Volkswirtschaftliche Gesamtrechnungen, Fachserie 18, Wiesbaden.

Sterr, H. (2007), Folgen des Klimawandels für Ozeane und Küsten, in: Endlicher, W. and F.W. Gerstengarbe (ed.), Der Klimawandel - Einblicke, Rückblicke und Ausblicke, Potsdam Institut für Klimafolgenforschung, Berlin, 86-97.

Sterr, H. (2008), Assessment of vulnerability and adaptation to sea-level rise for the coastal zone of Germany, Journal of Coastal Research 24(2), West palm beach (Florida), 380-393.

Storch, H., I. Meinke, R. Weisse, and K. Woth (2007), Regionaler Klimawandel in Deutschland. Wandel von Vulnerabilität und Klima: Müssen unsere Vorsorgeinstrumente angepasst werden? Workshop von DKKV und ARL, Hannover, 27.-28. Nov. 2006.

Tol, R.S.J. (2003), Is the Uncertainty about Climate Change too Large for Expected Cost-Benefit Analysis?, Climatic Change 56(3), 265-289.

Tol, R.S.J. (2005), Adaptation and mitigation: trade-offs in substance and methods, Environmental Science and Policy 8(6), 572-578.

Tol, R.S.J. (2007), The double trade-off between adaptation and mitigation for sea level rise: an application of FUND, Mitigation and Adaptation Strategies for Global Change 12(5), 741753.

Tol, R., R. Klein, and R. Nicholls (2008), Towards successful adaptation to sea-level rise along Europe's coasts, Journal of Coastal Reasearch 24(2), West palm beach (Florida), 432-442.

UBA (2005), Klimawandel in Deutschland - Vulnerabilität und Anpassungsstrategien klimaintensiver Systeme, UBA, Dessau.

UBA (2007), Hintergrundpapier “Neue Ergebnisse zu regionalen Klimaänderungen”. Das statistische Regionalisierungsmodell WETTREG, UBA, Dessau.

UBA (2008), Klimaauswirkungen und Anpassung in Deutschland - Phase 1: Erstellung regionaler Klimaszenarien für Deutschland, UBA, Dessau.

VDKI (2006), Jahresbericht 2006, Verein der Kohlenimporteure.

VDKI (2009), Jahresbericht 2009, Verein der Kohlenimporteure.

von Alten, G. (2006), Das Risikoverhalten von Landwirten - eine Studie am Beispiel der Erntemehrgefahrenversicherung, Cuvillier Verlag, Göttingen.

von Hauff, M. and K. Kluth (2006), Die energiewirtschaftliche Situation und Stand der Versorgungssicherheit in Deutschland während der Trockenperiode 2003, Diskussionsbeitrag 22-06, Technische Universität Kaiserslautern.

von Storch, H., I. Meinke, R. Weisse, and K. Woth (2007), Regionaler Klimawandel in Deutsch- 
land. Wandel von Vulnerabilität und Klima: Müssen unsere Vorsorgeinstrumente angepasst werden? Workshop von DKKV und ARL, Hannover, 27.-28. Nov. 2006.

Weisskopf, M.G., H.A. Anderson, S. Foldy, L.P. Hanrahan, K. Blair, T.J. Török, and P.D. Rumm (2002), Heat Wave Morbidity and Mortality, Milwaukee, Wis, 1999 vs. 1995: An Improved Response?, American Journal of Public Health 92(5), 830-833.

Weitzman, M. (2007), Structural Uncertainty and the Value of Statistical Life in the Economics of Catastrophic Climate Change, NBER Working Paper 13490, October 2007.

Weitzman, M. (2009), On Modeling and Interpreting the Economics of Catastrophic Climate Change, Review of Economics and Statistics 91(1), 1-19.

Wildasin, D.E. (2008), Disaster Policies: Some Implications for Public Finance in the U.S. Federation, Public Finance Review 36(4), 497-518.

Wittmann, E.J. and M. Baylis (2000), Climate Change: Effects on Culicoides-Transmitted Viruses and Implications for the UK, The Veterinary Journal 160, 107-117.

Woth, K. and von Storch, H. (2007), Klimawandel in Deutschland. Mögliche Zukünfte des Norddeutschen Küstenklimas, Version 28.12.2007, GKSS Research Centre.

ZEW (2009), Schwerpunkt Energiemarkt, Sonderteil ZEWnews, Juli/August 2009, Zentrum für Europäische Wirtschaftsforschung, Mannheim. 